\title{
Relationships between physico-chemical and microbiological parameters in the monimolimnion of a forest meromictic lake
}

\author{
Dorota GÓRNIAK, ${ }^{1}$ Renata TANDYRAK, ${ }^{2 *}$ Katarzyna PARSZUTO, ${ }^{2}$ Joanna MISIUN ${ }^{2}$ \\ ${ }^{1}$ Department of Microbiology, University of Warmia and Mazury in Olsztyn, Oczapowskiego 1A, 10-727 Olsztyn; ${ }^{2}$ Department of \\ Water Protection Engineering, University of Warmia and Mazury in Olsztyn, Prawocheńskiego 1, 10-720 Olsztyn, Poland \\ *Corresponding author: renatat@uwm.edu.pl
}

\begin{abstract}
This study describes the impact of environmental factors on prokaryotic community structure and dominant bacterial groups in the monimolimnion of a meromictic lake. The samples were taken between $10 \mathrm{~m}$ and $17 \mathrm{~m}$ from Zapadte lake in North-Eastern Poland between April and November in 2011. Meromictic lakes are important biogeochemical models because of their stratified chemical gradients and separation of redox reactions down the water column. We applied the Direct Epifluorescent Filter Technic (DEFT) and 16S rDNA PCR$D G G E$ fingerprinting methods. DAPI stained prokaryotic cells were counted measured and sorted by computer image analysis. In addition, the abundance (TCN), biomass (PB), average cell volume (ACV) and morphological structure of cells were determined. DNA was amplified using the universal bacterial primers-pair 341 GC/907r. Highly significant Spearman's rank correlations between total prokaryotic cell number, biomass and BOD, conductivity, total (TOC) and dissolved (DOC) organic carbon were determined. The prokaryotic biomass increased very substantially in the lower part of the monimolimnion. The morphological structure of the cells also changed with depth. Participation-curved forms in the biomass of prokaryotes significantly increased towards the bottom. A significant correlation ( $p<0.05)$ between prokaryotic biomass and their anaerobic metabolic products including: $\mathrm{NH}_{4}(r=0.75), \mathrm{H}_{2} \mathrm{~S}(r=0.45)$ and $\mathrm{PO}_{4}(r=0.68)$ was revealed. Multiple stepwise regression analysis showed the following factors determined prokaryotic abundance: conductivity, TN, depth, temperature, $\mathrm{Fe}$, DOC and Norg. $\left(r^{2}=0.89, \mathrm{P}<0.05\right)$, while conductivity, TOC, $\mathrm{H}_{2} \mathrm{~S}$ and $\mathrm{PO}_{4}$ influenced prokaryotic biomass at $r^{2}=0.92(P<0.05)$. Canonical correspondence analysis (CCA) indicated that conductivity, $\mathrm{H}_{2} \mathrm{~S}, \mathrm{DON}$. TOC, DOC, $\mathrm{N}$ tot, Norg, $\mathrm{NH}_{4}, \mathrm{Ptot}$, Porg, PO , and Mn explained changes in bacterial community structures in June and September, while the most important measured factor in November was temperature. DGGE banding patterns revealed similar bacterial community structures for June and September and slightly different for April. The bacterial diversity estimated from the number and intensity of specific fragments in DGGE profiles decreased with depth. Clear seasonal variability of bacterioplankton dominant OTUs composition was not observed.
\end{abstract}

Key words: Meromixis, monimolimnion, hydrogen sulphide, prokaryotes, bacterioplankton, 16S rDNA PCR-DGGE.

Received: August 2013. Accepted: March 2014.

\section{INTRODUCTION}

Permanent anoxic layers in natural freshwater basins are rare and of considerable interest to environmental investigations because of their potential undisturbed climax microbial communities and because of their relationship to an earlier biosphere. Meromictic lakes are interesting model systems for research in limnology for several other reasons, e.g. high physical stability of the water masses, clearly separated compartments and a relatively constant vertical stratification, a compact and stable transition zone between the oxic mixolimnion and anoxic monimolimnion and, in many cases, the presence of a dense microbial community in the redox transition zone (Bosshard et al., 2000; Rodrigo et al., 2001; Dunalska et al., 2004; Boehrer and Schultze, 2008; Dietz et al., 2012; Tylmann et al., 2012). Following Yoshimura's 1937 description of 44 meromictic lakes this number has increased.

The list compiled by Walker and Likens (1975) compri- sed 121 meromictic lakes throughout the world. Subsequently, Anderson et al. (1985) described approximately 100 lakes in North America which may be considered meromictic, and Hongve (2002) reported 9 in southeast Norway. Meromixis is a rare phenomenon in Poland too, documented only in several lakes. The small, in-forest Lake Zapadłe in Poland provides such an environment (Dunalska et al., 2004; Tandyrak et al., 2010). Mictic lake classification follows identification of permanent water stratification formed by mixolimnion and monimolimnion layers separated by a chemocline. In meromictic lakes, this chemocline separates circulating oxygenated and stagnant water layers. The water chemistry in this area results from differences in water oxygen concentration (Hakala et al., 2004), and microorganisms activity therein can result in permanent loss of particulate organic matter produced in the surface layer (Cole et al., 1993; Chróst and Siuda, 2006; Parszuto et al., 2009; Tandyrak et al., 2009). The monimolimnion doesn't interact directly with other water layers. It is isolated from gas 
exchange with the atmosphere and is thermally trapped between surface water and deep lake hypolimnion (Boehrer and Schultze, 2008). Its water normally has higher density, not only from temperature changes, but also from higher solute concentration which has increased solubility with decreasing oxygen concentration (Hakala et al., 2004). Because this zone is constantly exposed to high hydrostatic pressure, the concentration of gases such as $\mathrm{CO}_{2}$ and $\mathrm{H}_{2} \mathrm{~S}$ is a much higher here than in the mixolimnion. The cell electron acceptors oxidizing organic matter in the permanently anaerobic conditions are nitrates and sulfates. Meromictic lakes create extreme aquatic environments and enable study of relationships between two distinct habitats because of continuing presence of an oxic/anoxic boundary. Despite quite well documented research on this reservoir type, better understanding is required of the processes occurring in the deep deoxygenated, stagnant water of the monimolimnion to enable precise description of biogeochemical processes and matter flow in these ecosystems.

The aim of this study is to evaluate the dynamics of the major environmental factors in the monimolimnion of Lake Zapadke during the main growth season, and to determine the influence of these factors on microbiocenosis structure.

\section{METHODS}

Lake Zapadłe covers a 4.6 ha area with a maximum 18 $\mathrm{m}$ depth, and it is located in north eastern Poland in the Mazury Lake district (53॰48’32” N; 2006’29” S) (Fig. 1). It is a typical post-glacial, thawed-out reservoir where the lake basin forms a large natural hollow. On its northern, western and southern aspects, the lake's shores are surrounded by a steep $20 \mathrm{~m}$ scarp covered in old mixed forest stand. The surface inflow from the North ensures its flowlake status. Our study was carried out from April to November 2011. Water samples were collected in the deepest part of the lake, at one metre depth intervals from the 1017 metre deep hypolimnion layer using a 3.5-litre Ruttner sampler. Thermal-oxygen $\left(\mathrm{T}, \mathrm{O}_{2}\right)$ and conductivity $(\mathrm{C})$ were then determined at the full vertical section of the lake.

\section{Physico-chemical parameters}

Oxygen and temperature were determined with the optical oxygen probe ProOdo (YSL) and electrolyte conductivity by MultiLine probe (WTW). Colorimetric measurements of total phosphorus, phosphate and nitrate nitrogen (V) were made by NANOCOLOR spectrophotometer, while iron, manganese, ammonia and $\mathrm{H}_{2} \mathrm{~S}$ (as $\mathrm{HS}^{-}$) concentrations were determined by Merck SQ118 spectrophotometer. Following mineralisation with $\mathrm{H}_{2} \mathrm{SO}_{4}$ and $\mathrm{CuSO}_{4}$, the Kjeldahl nitrogen together with the ammonium nitrogen were established by distillation with 0.1 $\mathrm{M} \mathrm{HCl}$, and organic nitrogen was calculated as the difference between the Kjeldahl nitrogen and ammonium. After mineralization with $\mathrm{H}_{2} \mathrm{SO}_{4}$ and $\mathrm{K}_{2} \mathrm{~S}_{2} \mathrm{O}_{8}$ the total phosphorus plus the mineral phosphorus were determined with ammonium molybdate and $\mathrm{SnCl}_{2}(\lambda=690 \mathrm{~nm})$, while organic phosphorus was calculated as the difference bet-

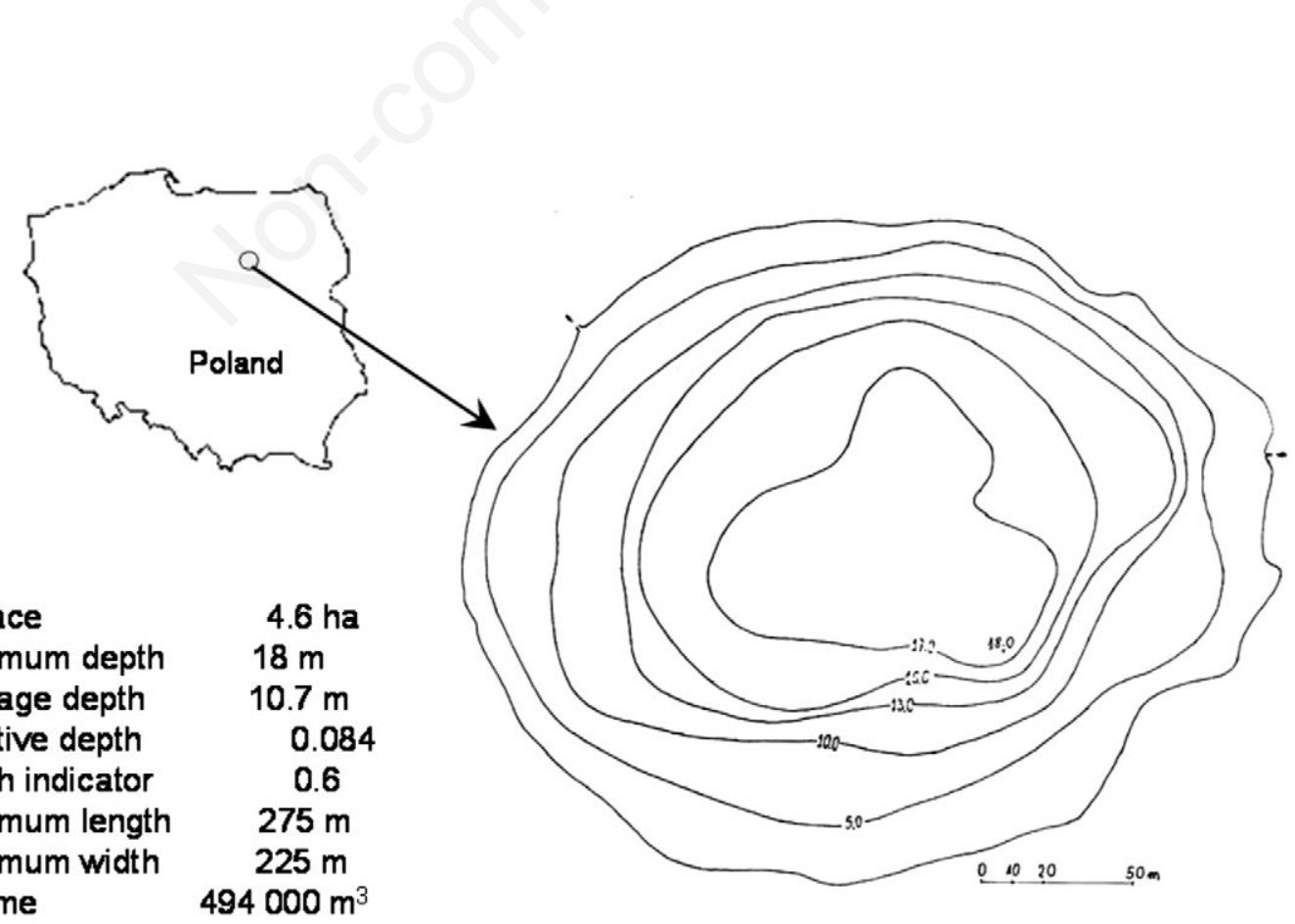

Fig. 1. Location and bathymetry of Lake Zapadłe. 
ween total phosphorus and phosphate. Biochemical oxygen demand (BOD) was established by dilution and chemical oxygen demand (COD-Mn) was determined with $0.01 \mathrm{M} \mathrm{KMnO}_{4}$.

For organic carbon fractions, the particular organic carbon (POC) and dissolved organic carbon (DOC) were separated by filtration through a $0.45 \mu \mathrm{m}$ diameter membrane made by Sartorius. Each filter was washed with $200 \mathrm{ml}$ of deionized water. Prior to organic carbon determination, a sample was acidified to $\mathrm{pH} 2$ with $2 \mathrm{M} \mathrm{HCl}$, and the inorganic carbon forms were removed by passing oxygen through the sample. The concentrations of non-volatile total organic carbon (TOC) and dissolved organic carbon (DOC) were determined by HACH IL 550 TOC-TN analyser, and particular organic carbon (POC) content was established by organic carbon concentration differences in the filtered and non-filtered samples (POC $=$ TOC-DOC).

Total cell number (TCN), prokaryotic biomass (PB) size distributions (ACV-Average Cell Volume) and morphological structure

The direct epifluorescent filter technique (DEFT) was used to examine bacteria. Triplicate water samples were preserved with buffered formalin to a final concentration of $2 \%$, and $0.5 \mathrm{ml} \mathrm{sub}$-samples were stained with DAPI (4'6-diamidino-2-phenolindole with $1 \mu \mathrm{g} \mathrm{ml}^{-1}$ final concentration - Porter and Feig, 1980). These were then filtered through Millipore GTBP $0.2-\mu \mathrm{m}$ black polycarbonate membrane filters mounted with Citifluor (Agar Scientific UK) on glass slides and cells calculated under epifluorescent microscopy. Between 500 and 1,000 DAPI stained cells in at least 10 digital images of each filter were counted and measured. The imaging analysis system consisted of an Olympus BX41 epifluorescence microscope and a highly sensitive Nikon DS-Fi 1C digital camera linked to a PC computer in NIS-Elements F 3.0 software. This recorded and processed the stained cells (Górniak et al., 2007), and total cell counts, average cell volume was established as in Świątecki (1997). The prokaryotic biomass (PB) was calculated by converting the DAPI-stained cell volume to carbon units using the 170 fg $\mathrm{C} \mu \mathrm{m}^{-3}$ biomass conversion factor (Norland, 1993).

\section{PCR-DGGE analysis}

PCR and Denaturing Gradient Gel Elecrtophoresis (DGGE) were instituted to study the diversity and the dynamics of the dominant bacterial communities in Lake Zapadłe monimolimnion. Bacterioplankton was collected by filtering $\sim 50 \mathrm{~mL}$ samples through $0.2 \mu \mathrm{m}$ PES filters (Pall Corporation, USA). DNA extraction from cells was achieved using the MoBio (Power Water) isolation kit (MoBio Laboratories Inc., Carlsbad, CA, USA) according to the manufacturer's protocol, and PCR amplification was performed on the V2-V5 regions of the 16S rRNA gene. Primers were 341f with GC clamp (CGC CCG CCG CGC CCC GCG CCC GGC CCG CCG CCC CCG CCC CCT ACG GGA GGC AGC AG), complementary to Escherichia coli numbering positions 341 to 357 and $907 \mathrm{r}$ (CCG TCA ATT CMT TTG AGT TT) complementary to positions 926 to 907 (Muyzer et al., 1993, 1998). The PCR $(50 \mu \mathrm{L})$ reaction contained 1xPCR buffer, $2.5 \mathrm{mM} \mathrm{MgCl}_{2}$, $200 \mu \mathrm{M}$ of each deoxynucleoside triphosphate, $0.25 \mu \mathrm{M}$ of each primer, 1,5 U Taq Polymerase (Sigma) and approximately 1-2 ng of template DNA $\mu \mathrm{L}^{-1}$. The following process was followed: $94^{\circ} \mathrm{C}$ for $5 \mathrm{~min}, 10$ touchdown cycles: $94^{\circ} \mathrm{C} 1 \mathrm{~min}, 65^{\circ} \mathrm{C}$ decrease $1^{\circ} \mathrm{C} /$ cycle, $72^{\circ} \mathrm{C} 3 \mathrm{~min}$. 20 standard cycles: $94^{\circ} \mathrm{C} 1 \mathrm{~min}$ and $55^{\circ} \mathrm{C} 1 \mathrm{~min}$ with a final cycle at $72^{\circ} \mathrm{C}$ for $5 \mathrm{~min}$. Amplification products were analysed by electrophoresis in 1\% wt/vol agarose gel, stained with ethidium bromide and separated using the D-Code Universal Mutation Detection System (BioRad, Hercules, CA, USA). DGGE was employed with 6\% wt/vol, 16x16 $\mathrm{cm}$ polyacrylamide gel (ratio of acrylamid to bisacrylamide $=37: 1)$ in a $1 \times$ TAE buffer $(40 \mathrm{mM}$ tris, $20 \mathrm{mM}$ acetic acid, $1 \mathrm{mM}$ EDTA, $\mathrm{pH} 8.0$ ) with a 35 to $70 \%$ denaturant gradient, where the reference $100 \%$ denaturant had $7 \mathrm{M}$ urea and $40 \%$ formamide. Electrophoresis was in 1xTAE buffer at a constant $60 \mathrm{~V}$ for $17 \mathrm{~h}$ at $60^{\circ} \mathrm{C}$.

The products of electrophoreses were stained by gently agitating the gel for $30 \mathrm{~min}$ in $100 \mathrm{ml}$ of 1 xTAE containing $5 \mu \mathrm{L}$ of a 1:10,000 dilution of SYBR Gold nucleic acid stain (Molecular Probes Inc., PoortGebouw, The Netherlands) and then rinsed in distilled water for $20 \mathrm{~min}$. DGGE gel images were then analysed by Quantity One software on a GelDoc gel documentation system (BioRad). Gel bands were identified in GelCompar software by creating the presence-absence matrix described by Crump and Hobbie (2005). Each band of a respective height within the gel represented a bacterial Operational Taxonomic Unit (OTU).

\section{Statistical analysis}

Spearman's rank correlation described the strength of interdependence between the studied microbial traits and environmental factors. Two-way ANOVA determined repetitive measurements of main microbiocenosis parameters consisting of abundance, biomass, cell volume and the biomass of the three rods, cocci, curved cell fractions and depth, period and interaction depth-period. Multiple stepwise regression analysis was conducted for major microbiological parameters as dependent variables abundance, biomass, cell volume and biomass of the three cell fractions. Analysis was by STATISTICA version 9 (StatSoft). The Canonical correspondence analysis (CCA) was conducted with Windows v. Canoco 4.5 statistical pack (ter Braak and Šmilauer, 2002). Microbiological data for each sample was analyzed in relation to environmental 
background, depth and period. In order to confirm the dominant taxonomic diversity in the samples, a DGGE analysis was performed. Phylotypes, defined by DGGE bands, were noted and counted for each sample lane, and bands in each sample were scored based on their presence or absence at each position. Species richness was determined as the number of bands resolved by PCR/DGGE in 1 sample lane. The similarity between the band patterns was calculated using the Dice coefficient and the clustering analysis was performed with the unweighted pairgroup method using arithmetic averages (UPGMA) for dendrogram construction.

\section{RESULTS}

An analysis of thermal, oxygen and conductivity profiles and hydrogen sulphide vertical distribution showed that the monimolimnion layer of the lake was below 10 $m$ depth (Fig. 2). Its temperature underwent very small variations of $0.1-0.2^{\circ} \mathrm{C}$. Despite the monimolimnion's stable conditions, significant seasonal variation was observed in the concentration and range of hydrogen sulphide. Its widest range occurred at the end of summer stagnation (below $9 \mathrm{~m}$ ) depth and its highest concentrations of over $8 \mathrm{mg} \mathrm{HS}^{-} \mathrm{dm}^{-3}$ were recorded in June. Conductivity in the monimolimnion layer from significant accumulation of ions ranged from 408 to $552 \mu \mathrm{S} \mathrm{cm}^{-1}$ (Fig. 2). A parallel increase in conductivity, nutrients $\left(\mathrm{NH}_{4}, \mathrm{PO}_{4}\right)$ and minerals $(\mathrm{Fe}, \mathrm{Mn})$ concentration was con- firmed by the very high $(\mathrm{P}<0.05)$ square of Pearson's correlation coefficients, respectively: $(\mathrm{r}=0.96),(\mathrm{r}=0.77)$, $(\mathrm{r}=0.82)$ and $(\mathrm{r}=0.70)$ (Fig. 3). Additional parameters with their largest concentrations included: ammonium $(0.28$ $\left.8.05 \mathrm{mg} \mathrm{dm}^{-3}\right)$, mineral phosphorus (0.121-1.818 mg P $\left.\mathrm{dm}^{-3}\right)$, iron $\left(0.10-1.14 \mathrm{mg} \mathrm{dm}^{-3}\right)$ and manganese $(0.47$ $\left.1.37 \mathrm{mg} \mathrm{dm}^{-3}\right)$. The monimolimnion water was liberally supplied with mineral phosphorus and ammonia from existent anaerobic conditions. There was also a significant accumulation of TOC, DOC, POC, BOD and COD-Mn organic matter. The vertical profile of organic carbon in particulate form indicated increased concentration between 12 and $14 \mathrm{~m}$ depth, resulting from the slow sedimentation of organic matter there. This effect was not observed during April. Changes in the physico-chemical ranges in subsequent months are summarized in Tab. 1.

High values for abundance, biomass cell size and highly variable microbiocenoses morphological structure were recorded in Lake Zapadłe's monimolimnion layer. The average TCN varied throughout this layer between $16 \times 10^{6} \mathrm{~mL}^{-1}$ cell in April and $14 \times 10^{6} \mathrm{~mL}^{-1}$ in the remaining period, while $\mathrm{PB}$ ranged from 396.02 to $461.80 \mu \mathrm{g} \mathrm{C}$ $\mathrm{L}^{-1}$, with the highest biomass of $912.33 \mu \mathrm{g} \mathrm{C} \mathrm{L}^{-1}$ registered in September (Tab. 2). Higher cell abundance and biomass were recorded in the lower monimolimnion (14-17 $\mathrm{m})$ than in the upper level $(10-13 \mathrm{~m})$ during this entire study period (Tab. 3). ACV varied seasonally with the highest value of $15 \mu \mathrm{m}^{3}$ observed both in June in the lower monimolimnion depths of 14-17 $\mathrm{m}$ and in September in

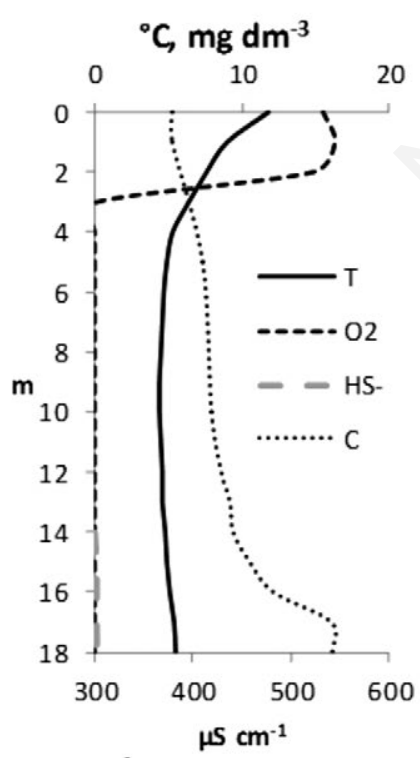

A

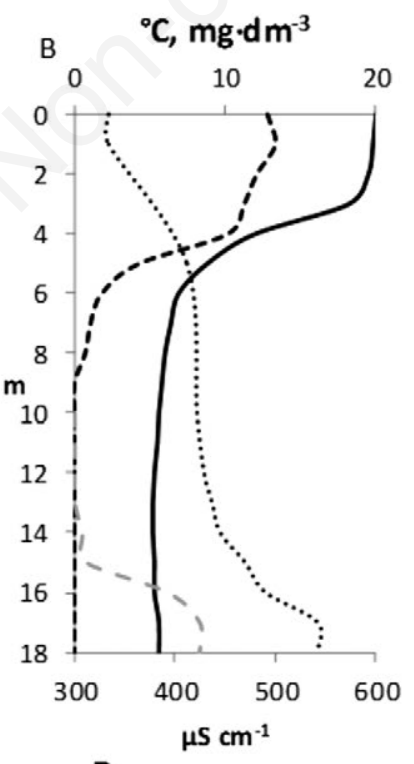

B
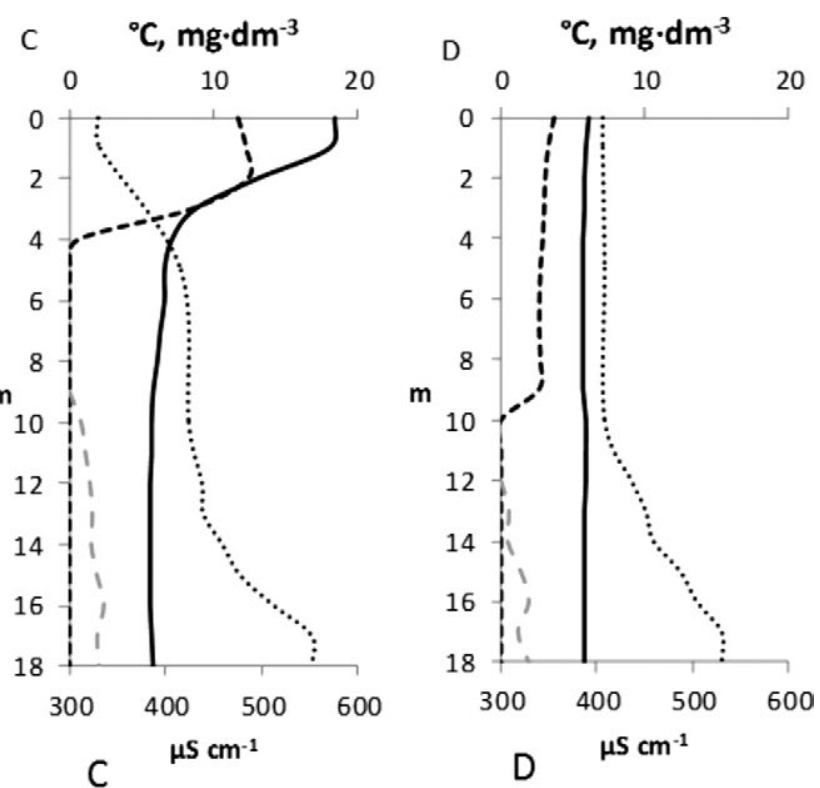

Fig. 2. Temperature (T), oxygen $\left(\mathrm{O}_{2}\right)$, hydrogen sulphide (HS $\left.{ }^{-}\right)$and conductivity $(\mathrm{C})$ in Lake Zapadłe during sampling period (A, April; B, June; C, September; D, November). 
its upper 10-13 m level. Cells average volume $>0.1 \mu \mathrm{m}^{3}$ was $94 \%$ in September, but only $6 \%$ in April. The three basic coccus, rods and curved morphological forms were analysed in monimolimnion of Lake Zapadłe water. Rods dominated microbial biomass in the monimolimnion layer throughout our study with approximately $63 \%$. Curved cells ranged from 13 to $38 \%$ in April and September, respectively, while cocci had the lowest content from 12 to $23 \%$ in those months. Our study revealed that the PB proportion of cocci and curved cells in the upper monimolimnion's $10-13 \mathrm{~m}$ level was similar at 18 and 23\%, respectively. However, curved cells biomass percentage increased significantly in the lower monimolimnion layers. Here, microbial biomass was composed of 57 to $73 \%$ rods, while curved cells recorded $59 \%$ and comprised $48 \%$ of June total biomass. Two-way ANOVA analysis determined increased prokaryote number and biomass in the lower monimolimnion (Tab. 4). Our results showed that the total cell number was equal in April and Septem-

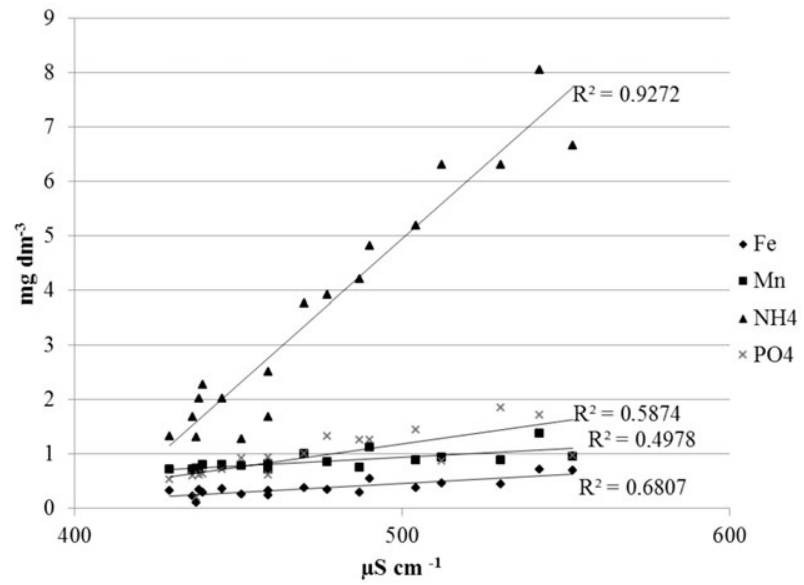

Fig. 3. Correlation between conductivity and the main ions (ammonium, phosphorus, iron and manganese) in Lake Zapadłe monimolimnion (Square of the Pearson correlation coefficient for the given data points).

Tab. 1. Average, maximum and minimum values of physico-chemical parameters in monimolimnion of Lake Zapadłe.

\begin{tabular}{|c|c|c|c|c|}
\hline Parameter & April & June & October & November \\
\hline Temperature $\left({ }^{\circ} \mathrm{C}\right)$ & $\begin{array}{c}4.83 \pm 0.34 \\
4.4-5.4\end{array}$ & $\begin{array}{c}5.63 \pm 0.17 \\
5.2-5.6\end{array}$ & $\begin{array}{c}5.63 \pm 0.05 \\
5.6-5.7\end{array}$ & $\begin{array}{c}5.83 \pm 0.05 \\
5.8-5.9\end{array}$ \\
\hline Reaction (pH) & $\begin{array}{l}7.43 \pm 0.22 \\
7.13-7.80\end{array}$ & $\begin{array}{l}7.34 \pm 0.12 \\
7.18-7.53\end{array}$ & $\begin{array}{l}7.43 \pm 0.15 \\
7.19-7.57\end{array}$ & $\begin{array}{l}7.55 \pm 0.17 \\
7.36-7.78\end{array}$ \\
\hline Conductivity $\left(\mu \mathrm{S} \mathrm{cm}^{-1}\right)$ & $\begin{array}{l}458 \pm 42 \\
419-541\end{array}$ & $\begin{array}{l}462 \pm 43 \\
422-542\end{array}$ & $\begin{array}{l}472 \pm 46 \\
424-552\end{array}$ & $\begin{array}{l}468 \pm 42 \\
408-530\end{array}$ \\
\hline $\mathrm{BOD}\left(\mathrm{mgO}_{2} \mathrm{dm}^{-3}\right)$ & $\begin{array}{l}11.8 \pm 5.7 \\
4.8-19.6\end{array}$ & $\begin{array}{l}12.3 \pm 6.5 \\
5.5-22.6\end{array}$ & $\begin{array}{l}9.6 \pm 4.7 \\
4.7-18.3\end{array}$ & $\begin{array}{l}10.7 \pm 4.6 \\
3.7-15.9\end{array}$ \\
\hline COD-Mn $\left(\mathrm{mg} \mathrm{O}_{2} \mathrm{dm}^{-3}\right)$ & $\begin{array}{c}7.54 \pm 2.13 \\
5.6-12\end{array}$ & $\begin{array}{l}11.75 \pm 2.89 \\
8.82-16.43\end{array}$ & $\begin{array}{l}9.72 \pm 1.23 \\
8.59-11.39\end{array}$ & $\begin{array}{c}13.96 \pm 3.89 \\
12.16-25.12\end{array}$ \\
\hline $\mathrm{N}-\mathrm{NH}_{4}\left(\mathrm{mg} \mathrm{Ndm}^{-3}\right)$ & $\begin{array}{l}3.04 \pm 2.21 \\
1.12-8.04\end{array}$ & $\begin{array}{l}3.18 \pm 2.58 \\
0.94-8.05\end{array}$ & $\begin{array}{c}3.44 \pm 2.25 \\
1.19-6.66\end{array}$ & $\begin{array}{l}3.14 \pm 2.15 \\
0.28-6.30\end{array}$ \\
\hline $\mathrm{N}$ org $\left(\mathrm{mg} \mathrm{Ndm}^{-3}\right)$ & $\begin{array}{l}0.048 \pm 0.007 \\
0.042-0.062\end{array}$ & $\begin{array}{c}0.015 \pm 0.013 \\
0.000-0.043\end{array}$ & $\begin{array}{l}0.013 \pm 0.017 \\
0.000-0.038\end{array}$ & $\begin{array}{c}0.052 \pm 0.001 \\
0.035-0.059\end{array}$ \\
\hline $\mathrm{PO}_{4}\left(\mathrm{mg} \mathrm{Pdm}^{-3}\right)$ & $\begin{array}{c}0.86 \pm 0.48 \\
0.433-1.818\end{array}$ & $\begin{array}{c}0.83 \pm 0.53 \\
0.212-1.265\end{array}$ & $\begin{array}{c}0.78 \pm 0.30 \\
0.427-1.332\end{array}$ & $\begin{array}{c}1.01 \pm 0.50 \\
0.234-1.264\end{array}$ \\
\hline $\mathrm{P}$ org $\left(\mathrm{mg} \mathrm{Pdm}^{-3}\right)$ & $\begin{array}{c}0.40 \pm 0.32 \\
0.127-0.977\end{array}$ & $\begin{array}{c}0.37 \pm 0.15 \\
2.219-0.662\end{array}$ & $\begin{array}{c}0.96 \pm 0.99 \\
0.213-2.658\end{array}$ & $\begin{array}{c}0.48 \pm 0.46 \\
0.060-1.295\end{array}$ \\
\hline $\mathrm{Fe}\left(\mathrm{mg} \mathrm{dm}^{-3}\right)$ & $\begin{array}{c}0.48 \pm 0.3 \\
0.27-1.14\end{array}$ & $\begin{array}{c}0.38 \pm 0.20 \\
0.10-0.72\end{array}$ & $\begin{array}{c}0.40 \pm 0.14 \\
0.29-0.70\end{array}$ & $\begin{array}{c}0.28 \pm 0.10 \\
0.12-0.44\end{array}$ \\
\hline $\operatorname{Mn}\left(\mathrm{mg} \mathrm{dm}^{-3}\right)$ & $\begin{array}{c}0.76 \pm 0.26 \\
0.55-1.28\end{array}$ & $\begin{array}{c}0.93 \pm 0.24 \\
0.71-1.37\end{array}$ & $\begin{array}{c}0.85 \pm 0.08 \\
0.74-0.96\end{array}$ & $\begin{array}{l}0.74 \pm 0.14 \\
0.47-0.89\end{array}$ \\
\hline $\mathrm{H}_{2} \mathrm{~S}\left(\mathrm{mg} \mathrm{HS}^{-} \mathrm{dm}^{-3}\right)$ & $\begin{array}{c}0.11 \pm 0.06 \\
0.02-0.152\end{array}$ & $\begin{array}{c}2.26 \pm 3.46 \\
0.02-8.3\end{array}$ & $\begin{array}{l}1.66 \pm 0.49 \\
0.82-2.39\end{array}$ & $\begin{array}{l}1.10 \pm 0.01 \\
0.47-1.93\end{array}$ \\
\hline $\mathrm{DOC}$ & $\begin{array}{l}5.12 \pm 0.48 \\
4.66-5.75\end{array}$ & $\begin{array}{l}5.38 \pm 1.03 \\
4.50-7.51\end{array}$ & $\begin{array}{l}5.44 \pm 0.29 \\
5.17-6.00\end{array}$ & $\begin{array}{l}5.58 \pm 0.41 \\
4.91-5.98\end{array}$ \\
\hline POC & $\begin{array}{c}2.64 \pm 1.39 \\
1.62-5.64\end{array}$ & $\begin{array}{c}2.06 \pm 0.91 \\
1.42-4.07\end{array}$ & $\begin{array}{l}1.76 \pm 0.40 \\
1.33-2.44\end{array}$ & $\begin{array}{l}1.23 \pm 0.06 \\
0.54-2.39\end{array}$ \\
\hline
\end{tabular}

BOD, biochemical oxygen demand; $C O D$, chemical oxygen demand; $D O C$, dissolved organic carbon; $P O C$, particular organic carbon. 
ber at approximately $29 \times 10^{6}$ cells cm $\mathrm{cm}^{-3}$, and that their biomass exceeded $850 \mu \mathrm{g} \mathrm{C} \mathrm{dm}{ }^{-3}$ in June and November. Highly significant correlations at $\mathrm{P}<0.001$ were recorded between depth and TCN and the prokaryotic biomass and individual morphological forms' total biomass (Tab. 4). Very high significant Spearman's rank correlations (Tab. 5) also existed between cell number, biomass and selected morphological forms and most physico-chemical parameters. But the relationships exhibited many variations. For example: i) hydrogen sulphide had significant correlation with $\mathrm{PB}$ and ACV only in curved prokaryotic biomass; ii) very high correlation existed for TCN and PB with conductivity, BOD, total nitrogen, ammonium, total phosphorus and phosphates iii) the effect of temperature, DOC and biomass oxidation ability on the percentage of curved cells was noted throughout the entire 10-17 m deep monimolimnion waters and this phenomenon was especially apparent in June and September; iv) the influence of oxygen, saturation and $\mathrm{pH}$ on average cell volume and percentage of rods and cocci in microbiocenosis was registered in April, June and November at 10-14 m depth in the upper monimolimnion; v) the impact of POC on rods and coccus shaped cells biomass was evident in April and June at 13-17 $\mathrm{m}$ in the lower monimolimnion; and vi) CCA revealed the impact of physico-chemical parameters on most bacterioplankton biomass during the June-November growing season at the extreme 15-17 m monimolimnion depth. Multiple stepwise regression analysis showed that the following factors determined TCN: conductivity, TN, depth, temperature, Fe, DOC and Norg. $\left(\mathrm{r}^{2}=0.89, \mathrm{P}<0.05\right)$, while conductivity, TOC, $\mathrm{HS}^{-}$and $\mathrm{PO}_{4}$ influenced $\mathrm{PB}\left(\mathrm{r}^{2}=0.92, \mathrm{P}<0.05\right)$.

The analysis of DGGE banding patterns showed 48 Operational Taxonomic Unit-s (OTUs) defined in Lake Zapadłe's monimolimnion. The OTU numbers at the studied months in the water column were as follows: 29 in April, 41 in Jun, 26 in September and 38 in November. CCA indicated a clear relationship between most environmental factors and bacterial OTUs in the monimolimnion water layer in June and September (Fig. 4). Our results showed a decrease in diversity, but an increase in intensity of some of the populations of Bacteria with increasing depth, we also found that numerous dominant bacterial populations were present throughout the entire monimolimnion water column. Clear seasonal variability in bacterioplankton OTUs composition was not observed. Our OTUs UPGMA cluster analysis results revealed similarity in June and September samples, with less similarity apparent in April. However, the June samples of the $10 \mathrm{~m}$ and $17 \mathrm{~m}$ clusters were closer to April than to September

Tab. 2. The structure of microbiocenosis in monimolimnion Lake Zapadłe during the sampling period.

\begin{tabular}{lccccccccc}
\hline Month & $\begin{array}{c}\mathrm{TCN} \\
\left(10^{6} \mathrm{~mL}^{-1}\right)\end{array}$ & $\begin{array}{c}\mathrm{ACV} \\
\left(\mu \mathrm{m}^{3}\right)\end{array}$ & $\begin{array}{c}\mathrm{PB} \\
(\mu \mathrm{g} \mathrm{C} \mathrm{L})\end{array}$ & $\begin{array}{c}\text { Rods } \\
\text { in PB } \\
(\%)\end{array}$ & $\begin{array}{c}\text { Cocci } \\
\text { in PB } \\
(\%)\end{array}$ & $\begin{array}{c}\text { Curved cells } \\
\text { in PB } \\
(\%)\end{array}$ & $\begin{array}{c}\text { Rods } \\
\text { in TCN } \\
(\%)\end{array}$ & $\begin{array}{c}\text { Cocci } \\
\text { in TCN } \\
(\%)\end{array}$ & $\begin{array}{c}\text { Curved cells } \\
\text { in TCN } \\
(\%)\end{array}$ \\
\hline April & $15.65^{\mathrm{a}}$ & 0.09 & 396.02 & 66.8 & 12.5 & 13.3 & 63.1 & 30.9 & 6.1 \\
& $(10.08-26.91)^{\mathrm{b}}$ & $(0.07-0.10)$ & $(269.35-636.85)$ & $(54.5-83.6)$ & $(21.5-39.1)$ & $(14.7-29.2)$ & $(61.0-65.4)$ & $(28.0-33.5)$ & $(4.9-7.0)$ \\
\hline June & 13.51 & 0.15 & 447.58 & 64.7 & 21.9 & 27.4 & 63.8 & 25.6 & 10.7 \\
& $(8.80-24.10)$ & $(0.11-0.16)-(276.57-854.46)$ & $(59.5-77.1)$ & $(15.6-26.4)$ & $(19.6-42.9)$ & $(58.6-68.7)$ & $(21.2-30.9)$ & $(8.0-16.8)$ \\
\hline September & 14.96 & 0.14 & 461.08 & 61.6 & 23.4 & 38.3 & 62.2 & 21.1 & 16.7 \\
& $(8.07-29.39)$ & $(0.12-0.15)$ & $(270.67-912.33)$ & $(50.0-64.1)$ & $(15.4-18.9)$ & $(34.2-46.6)$ & $(60.0-65.4)$ & $(18.1-25.1)$ & $(13.7-18.8)$ \\
\hline November & 13.73 & 0.12 & 424.44 & 63.0 & 19.9 & 28.6 & 65.8 & 23.5 & 9.8 \\
& $(6.62-19.88)$ & $(0.11-0.15)$ & $(190.56-589.31)$ & $(59.0-67.5)$ & $(15.4-24.8)$ & $(14.1-40.1)$ & $(59.4-71.7)$ & $(20.1-29.7)$ & $(5.4-11.9)$ \\
\hline
\end{tabular}

$T C N$, total cell number; $A C V$, average cell volume; $P B$, prokaryotic biomass; ${ }^{a}$ average, ${ }^{b}$ range of variation.

Tab. 3. The structure of microbiocenosis in upper and lower monimolimnion during the sampling period.

\begin{tabular}{lccccccccc}
\hline Monimolimnion & $\begin{array}{c}\mathrm{TCN} \\
\left(10^{6} \mathrm{~mL}^{-1}\right)\end{array}$ & $\begin{array}{c}\mathrm{ACV} \\
\left(\mu \mathrm{m}^{3}\right)\end{array}$ & $\begin{array}{c}\mathrm{PB} \\
\left(\mu \mathrm{g} \mathrm{C} \mathrm{L}^{-1}\right)\end{array}$ & $\begin{array}{c}\text { Rods } \\
\text { in PB } \\
(\%)\end{array}$ & $\begin{array}{c}\text { Cocci } \\
\text { in PB } \\
(\%)\end{array}$ & $\begin{array}{c}\text { Curved cells } \\
\text { in PB } \\
(\%)\end{array}$ & $\begin{array}{c}\text { Rods } \\
\text { in TCN } \\
(\%)\end{array}$ & $\begin{array}{c}\text { Cocci } \\
\text { in TCN } \\
(\%)\end{array}$ & $\begin{array}{c}\text { Curved cells } \\
\text { in TCN } \\
(\%)\end{array}$ \\
\hline $\begin{array}{l}\text { Upper } \\
10-13 \mathrm{~m}\end{array}$ & $9.90^{\mathrm{a}}$ & 0.12 & 294.39 & 65.7 & 18.3 & 23.6 & 65.9 & 24.1 & 10.0 \\
\hline Lower & $(6.62-14.51)^{\mathrm{b}}$ & $(0.10-0.15)$ & $(190.56-452.77)$ & $(59.0-83.6)$ & $(15.4-32.1)$ & $(14.1-46.6)$ & $(62.2-71.7)$ & $(18.1-30.7)$ & $(5.4-18.8)$ \\
$14-17 \mathrm{~m}$ & 18.40 & 0.14 & 572.42 & 62.40 & 21.6 & 29.7 & 61.6 & 26.9 & 11.5 \\
& $(11.97-29.39)$ & $(0.07-0.16)$ & $(304.59-871.92)$ & $(57.5-73.2)$ & $(15.6-39.1)$ & $(15.7-47.9)$ & $(58.6-65.5)$ & $(21.2-33.5)$ & $(4.9-18.1)$ \\
\hline
\end{tabular}

$T C N$, total cell number; $A C V$, average cell volume; $P B$, prokaryotic biomass; ${ }^{a}$ average, ${ }^{b}$ range of variation. 
(Fig. 5). Throughout the study period, the following were found: i) 13 joint OTUs in all seasons; ii) one was common only in April and September; iii) 9 were common in June and September; iv) 5 were common in September and November and 2 were common in April and November. DGGE revealed 3 unique OTUs in April, 7 in June, none in September and 6 in November (Fig. 6A).

An analysis of the OTUs in the upper (10-13 m) and lower (14-17 m) monimolimnion throughout the study pe- riod showed 48 phylotypes in the upper layer and 44 in the lower. In this, it was found that 38 OTUs occurred in both layers. It was also found that 5 OTUs occurred only in the upper monimolimnion and 8 occurred only in the lower monimolimnion (Fig. 6B).

\section{DISCUSSION}

The chemocline (defined as a layer of thermally-insulating mixo- and monimolimnion) in Lake Zapadłe can

Tab. 4. Two-way ANOVA of repetitive measurements.

\begin{tabular}{lccc}
\hline Microbiological parameters & Depth (A) & $\begin{array}{c}\text { Level of significance P } \\
\text { Month (B) }\end{array}$ & Interaction (A and B) \\
\hline TCN $\left(10^{6}\right.$ cells $\cdot \mathrm{mL}^{-1)}$ & $<0.001$ & $<0.001$ & $<0.001$ \\
\hline $\mathrm{ACV}\left(\mu \mathrm{m}^{3)}\right.$ & $>0.05$ & $<0.001$ & $<0.001$ \\
\hline $\mathrm{PB}\left(\mu \mathrm{g} \mathrm{C} \mathrm{L}^{-1}\right)$ & $<0.001$ & $<0.001$ & $<0.001$ \\
\hline B-Rods $\left(\mu \mathrm{g} \mathrm{C} \mathrm{L}^{-1}\right)$ & $<0.001$ & $>0.05$ & $<0.001$ \\
\hline B-Cocci $\left(\mu \mathrm{g} \mathrm{C} \mathrm{L}^{-1}\right)$ & $<0.001$ & $>0.05$ & $>0.05$ \\
\hline B-Curved $\left(\mu \mathrm{g} \mathrm{C} \mathrm{L}^{-1}\right)$ & $<0.001$ & $>0.05$ & $<0.001$ \\
\hline
\end{tabular}

$T C N$, total cell number; ACV, average cell volume; PB, prokaryotic biomass; B-Rods, biomass rods; B-Cocci, biomass cocci; B-Curved, biomass curved cells.

Tab. 5. Spearman's rank correlation. Coefficients of correlation are essential $\mathrm{P}<0.05$ ( $\mathrm{n}=28)$.

\begin{tabular}{|c|c|c|c|c|c|c|}
\hline Variable & Total cell numbers & Average cell volume & $\begin{array}{l}\text { Prokaryotes } \\
\text { biomass }\end{array}$ & Biomass rods & Biomass cocci & Biomass curved \\
\hline Depth & 0.86 & 0.06 & 0.82 & 0.82 & 0.84 & 0.68 \\
\hline Temperature & 0.03 & 0.15 & 0.11 & 0.09 & -0.12 & 0.36 \\
\hline $\mathrm{pH}$ & -0.73 & 0.01 & -0.67 & -0.71 & -0.82 & -0.46 \\
\hline Conductivity & 0.83 & 0.17 & 0.81 & 0.81 & 0.77 & 0.77 \\
\hline BOD & 0.85 & -0.04 & 0.79 & 0.78 & 0.85 & 0.56 \\
\hline COD-Mn & 0.34 & 0.23 & 0.39 & 0.43 & 0.34 & 0.40 \\
\hline Ammonium & 0.80 & 0.12 & 0.75 & 0.75 & 0.76 & 0.71 \\
\hline $\mathrm{N}$ org & 0.12 & -0.34 & 0.09 & 0.02 & 0.09 & -0.14 \\
\hline $\mathrm{NO}_{3}$ & 0.51 & -0.51 & 0.41 & 0.46 & 0.56 & 0.01 \\
\hline $\mathrm{PO}_{4}$ & 0.71 & 0.15 & 0.68 & 0.69 & 0.69 & 0.67 \\
\hline P org & 0.53 & 0.18 & 0.53 & 0.55 & 0.49 & 0.54 \\
\hline $\mathrm{Fe}$ & 0.65 & 0.03 & 0.59 & 0.61 & 0.68 & 0.55 \\
\hline $\mathrm{Mn}$ & 0.68 & 0.32 & 0.70 & 0.72 & 0.63 & 0.79 \\
\hline $\mathrm{H}_{2} \mathrm{~S}$ & 0.33 & 0.57 & 0.45 & 0.41 & 0.22 & 0.88 \\
\hline TOC & 0.54 & 0.01 & 0.50 & 0.51 & 0.53 & 0.33 \\
\hline DOC & 0.53 & 0.08 & 0.54 & 0.51 & 0.47 & 0.57 \\
\hline $\mathrm{POC}$ & 0.09 & -0.09 & 0.04 & 0.09 & 0.16 & -0.15 \\
\hline
\end{tabular}

BOD, biochemical oxygen demand; COD, chemical oxygen demand; TOC, total organic carbon DOC, dissolved organic carbon; POC, particular organic carbon. 
be found at a depth of 10 metres and it induces typical thermal stratification above it, exactly as occurs in all deep temperate zone reservoirs (Klimaszyk et al., 2006; Boehrer and Schultze, 2008). The area of sharp changes in water chemistry in stratified water reservoirs is a derivative of the differences in the oxygen concentration and often occurs in metalimnion (Peduzzi et al., 2003). Nevertheless, as earlier (Tandyrak et al., 2010) and current analyses have shown, the biggest changes in conditions and habitats depend on the season and the position in these upper 13 to $14 \mathrm{~m}$ (upper monimolimnion). In addition, this lake's location makes it difficult to get wind on the water surface. The morphometric characteristics (especially very high value of relative depth 0.0854 ) resist water circulation, so there is always an almost immobile water layer deprived of oxygen and gas exchange, but rich in nutrients and dissolved salts (Tylmann et al., 2012). The chemocline location in Lake Zapadłe at 13-14 m differs to most meromictic lakes (Hakala, 2004), but its position here is confirmed by its characteristically increased conductivity, its POC profile, the microorganisms present and the slight rise in thermal conditions. Higher water temperature is characteristic for meromictic lakes because of the accumulation of large amounts of organic matter and degradation products (Tandyrak and Parszuto, 2006). Permanent stagnation and lack of contact with the atmosphere caused decomposing metabolic products to accumulate in the monimolimnion layer. These increased the concentration of nutrient salts and substances from organic matter digestion and anaerobic decomposition. Together with summer thermal stratification, these conditions induced hydrogen sulphide production (Tylmann et al., 2012). This gas was then present in the deoxygenated layer, a few metres below the oxygenated zone. Kondo et al. (2006) suggested that anaerobic sulfate-reducing bacteria were responsible for its formation. The ion concentration in the monimolimnion increased with depth $(\mathrm{r}=0.98, \mathrm{P}<0.05)$, regardless of temperature $(\mathrm{r}=0.19, \mathrm{P}>0.05)$. Rodrigo et al. (2001) reported that a parallel increase in dissolved gases and minerals is typical, and this was confirmed here. Increased electrolyte concentration and the density gradient rise in the lower lake layer created Lake Zapadłe's anoxic water layer changed consistently throughout the study period. Spring water circulation at the end of April and summer thermal stratification changed it from the 3 metre mark below the

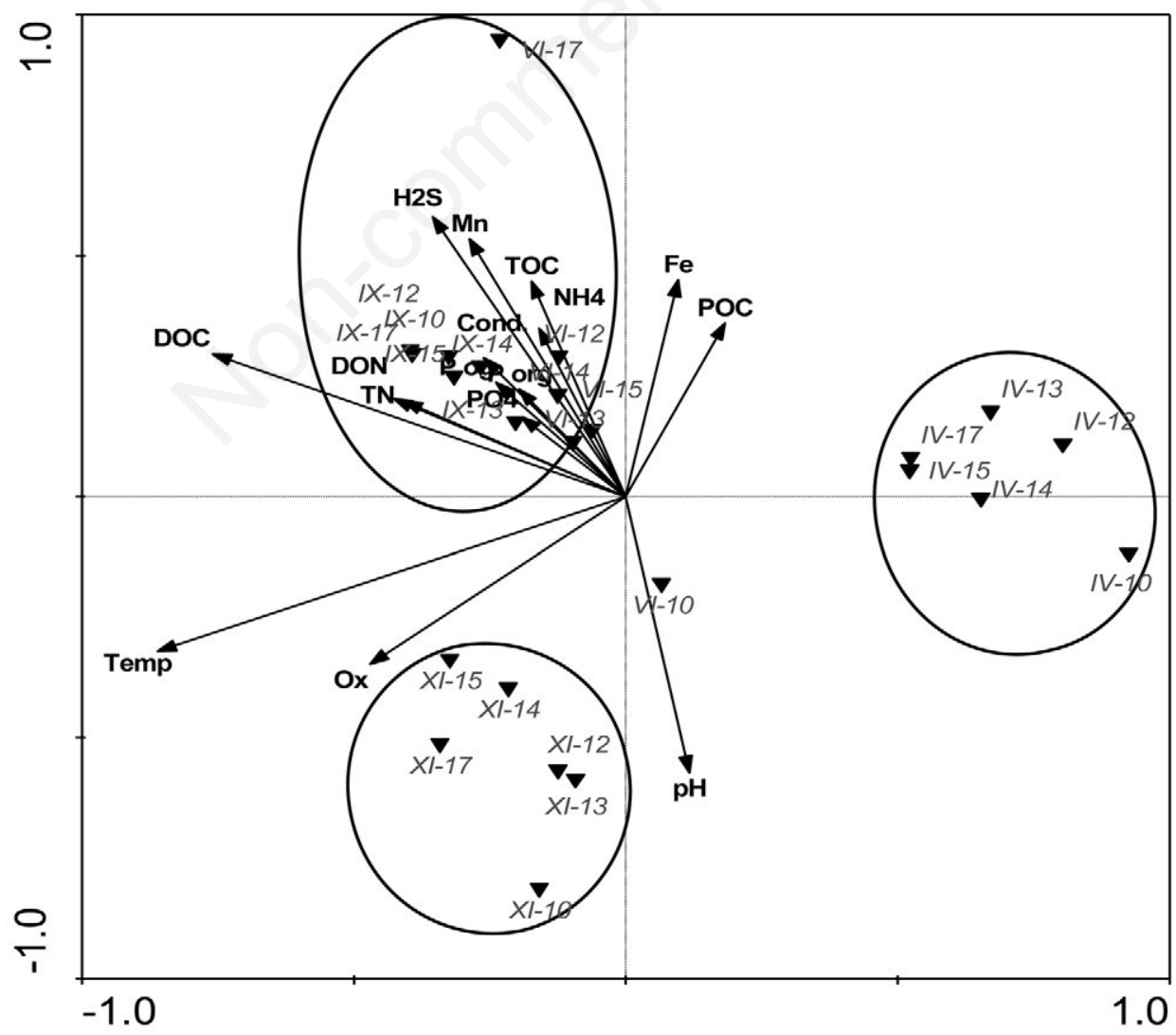

Fig. 4. Canonical correspondence analysis of DGGE banding patterns in the study period (months IV, VI, IX, XI) and environmental data. 
surface. Changes in consistently continued until autumn circulation when these were most apparent at $10 \mathrm{~m}$ depth. This latter phenomenon was most likely related to the loss of oxygen in decomposing organic matter descending from the lake's surface (Klimaszyk et al., 2006). The increases in electrolyte concentration and density in the lower lake layer created a barrier to water exchange between the mixo- and monimolimnion, thus eliminating oxygenation (Socolofsky, 2004). In November, BOD in the lowest part of the monimolimnion was approximately $22.6 \mathrm{mg} \mathrm{O}_{2} \mathrm{dm}^{-3}$ and COD-Mn was $25.1 \mathrm{mg} \mathrm{O}_{2} \mathrm{dm}^{-3}$. These values can be attributed to the fact that this layer is constantly enriched by sedimented material from the surface and its consequent increase in density (Ambrosetti and Barbanti, 2005). This layer is therefore quite stable because permanent stratification significantly prohibits the passage of mineral and organic matter from monimolimnion to mixolimnion (Galas, 2003; Klimaszyk et al., 2006).

Organic carbon in stagnant water reservoirs exists in the dissolved form (DOC) and in suspension (POC). In addition, biomass from living organisms and dead organic matter forms the source and regulation of POC in this environment. Further, the presence of these organic carbon types depends on the intensity of primary and secondary production in the reservoir (Tandyrak and Parszuto, 2006; Parszuto, 2008; Parszuto et al., 2009). The DOC indicates pollution by labile and refractory organic matter, mainly evolving from microbial degradation of organic metabolism (Hudson et al., 2003). Catchment areas provide an important source of this component, especially in forested areas (Górniak, 1996), and forests here cover approximately $70 \%$ of the Lake Zapadłe catchment area. Spatial and seasonal variability affected both TOC fractions. These effects were highest for monimolimnion DOC which was 3-times higher than the POC value throughout the study period. This illustrates the benefits derived from degradation products in this layer. DOC concentration in the deoxygenated layer of lake increased with depth, but this was not observed in POC which differed significantly

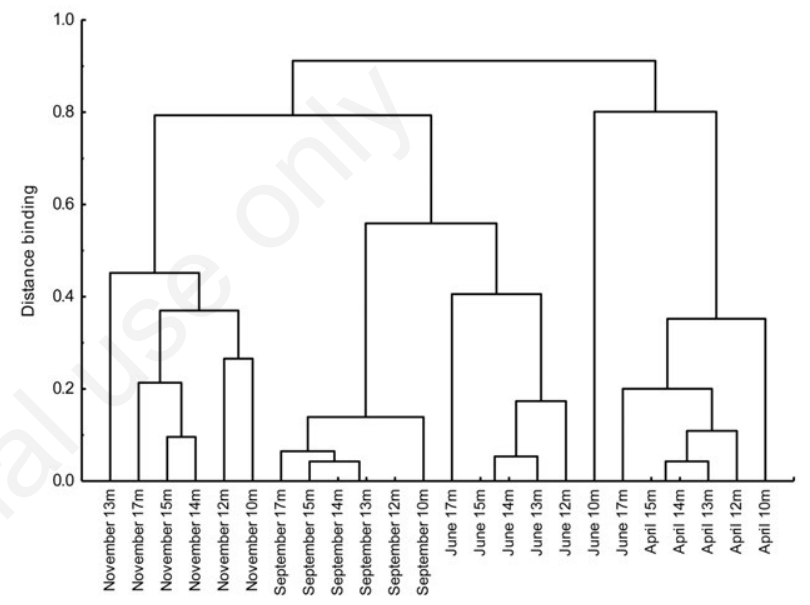

Fig. 5. A dendrogram (cluster analysis) by UPGMA of the similarity of DGGE banding patterns between samples in the monimolimnion water column in Lake Zapadłe.

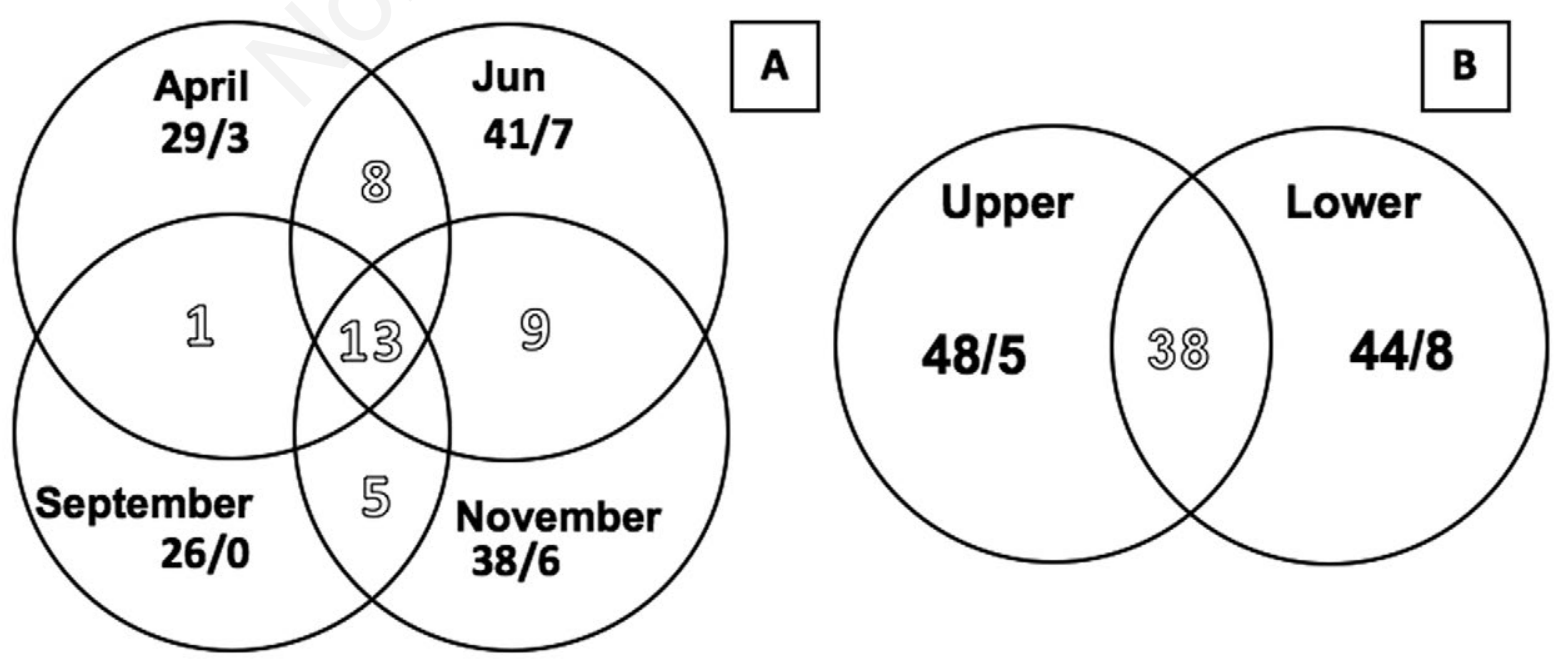

Fig. 6. Number of operational taxonomic units (OTUs) revealed by DGGE related to month (period) (A) and depth (upper: 10-13 m, and lower: 14-17 m monimolimnion) (B). Black numbers, all/unique OTUs in a month or depth; white numbers, OTUs shared with neighboring month or depth. 
throughout the study period $(\mathrm{r}=-0.63, \mathrm{P}<0.05)$. This phenomenon may be related to individual bacterioplankton metabolism.

Meromixis favours enrichment of lower lake layers with dissolved substances from biological activity. This occurs because of intensive photosynthesis in the upper layers of the reservoir and the microbial decomposition of organic matter nearer the lake bed (Boehrer and Schultze, 2006). The final degradation products enhance meromixis by increasing monimolimnion density. The increasing prokaryotes number and biomass in the lower monimolimnion of studied lake was described earlier. Górniak et al. (2007) reported that both these parameters depend on the concentration of organic carbon in the water because this provides the substrate and energy base for inorganic suspensions and for heterotrophic bacteria settling on organic detritus. A high positive correlation of Spearmaan's rank was recorded in the monimolimnion between TCN, PB and TOC, and DOC. However, no correlation existed between these indicators and POC. Vertical change in the total number of prokaryotes and the fraction of organic carbon indicate cell suspension transformation (Dunalska et al., 2004). Significant correlations of Spearman ranks at $\mathrm{P}<0.05(\mathrm{n}=28)$ were also recorded between TCN and anaerobic metabolism products: ammonia $(\mathrm{r}=0.80)$ and phosphate $(\mathrm{r}=0.71), \mathrm{PB}$ and ammonia $(\mathrm{r}=0.75)$ and phosphate $(\mathrm{r}=0.68)(\mathrm{Tab} .3)$. These relationships indicate the large percentage of sulfate-reducing bacteria in Lake Zapadłe's deoxygenated monimolimnion. Tandyrak et al. (2009) reported the common occurrence of this phenomenon in this type of reservoir. Strong correlations of Spearman's ranks between the TCN, PB and iron content $(\mathrm{r}=0.65$ and $\mathrm{r}=0.59)$ were also registered. According to Sørensen (1982), the release of iron (II) and phosphorus from sediment results from increased cell activity. However, denitrifying bacteria can also use iron (III) when nitrate is absent as electron acceptor. While no spatial changes were observed in the ACV in Lake Zapadłe's deoxygenated waters, seasonal changes were noted with maximum monimolimnion ACV registered in June and September. This was most likely caused by algal blooms in summer and intensive sedimentation in autumn (Górniak et al., 2007). Cole et al. (1993) determined that this was due to the following influential factors: anaerobic conditions, the constant low temperature of $4-6^{\circ} \mathrm{C}$ and high nutrient availability. In addition, there are less predators to attack bacteria in these anaerobic conditions (Oikonomou et al., 2014). Our results revealed that rods dominated cocci and curved shape prokaryotic plankton throughout the entire study period. However, the share of curved cells with their vertical distribution increases at lower lake levels. Górniak et al. (2007) and Tandyrak et al. (2009) reported a huge increase in prokaryote biomass with depth, especially a si- gnificant proportion of cells with a curved shape in meromictic lakes where they formed $27 \%$ of the lake-bed biomass. Both TCN and PB levels increased in the chemocline, and Tonolla et al. (2005) reported this as a characteristic phenomenon of deoxygenated monimolimnion layers. In our study, we observed a decrease of DGGE bacterial OTUs number with depth. Øvreås et al. (1997) and Lehours et al. $(2005,2007)$ also found that the structures of both the bacterial and archaeal communities in the anoxic zone of a meromictic lake changed with depth and the number of Bacterial OTUs bands decreased with depth. On the other hand, the numbers of Archaeal populations usually increased with depth (Øvreås et al. 1997, Lehours et al. 2005).

This is most likely due to the significant changes in water chemistry, highlighted by an increased electrolyte conductivity gradient in the layer below. This was supported by very high correlation ratios for total cell number $(\mathrm{r}=0.83)$ and biomass: rods $(\mathrm{r}=0.81)$, cocci $(\mathrm{r}=0.77)$ and curved bacteria $(r=0.77)$. Finally, Spearman's rank correlation showed highly significant relationships between conductivity and: BOD (0.91), ammonium nitrogen (0.96), phosphate (0.91), iron (0.77) and manganese $(0.82)$. No significant correlations observed for most parameters correlated with $\mathrm{POC}$, organic nitrogen, nitrate and COD-Mn and the spatial occurrence of procaryotes were found in this study. This suggests that other physicochemical parameters predominantly act in the structure of procaryote communities and/or that the complex network of metabolic interactions established by anaerobic microorganisms governs the organization of microbial communities. This hypothesis could explain the diversity of monimolimnion bacterial populations. It may be possible that microorganisms which exhibit anaerobic metabolism, which is less energetically efficient than oxygen-dependent metabolism, maintain a higher diversity of energetic pathways in anoxic environments. This phenomenon could lead to the retention of higher metabolic diversity and, as postulated by Humayoun et al. (2003), ecological forces that act to structure aerobic microbial communities are fundamentally different from those that act to structure anaerobic microbial communities.

\section{CONCLUSIONS}

Our research broadens knowledge of meromictic lake functioning. We found that the isolated stagnant monimolimnion water layer interacts with the mixolimnion by continually supplying sedimented organic matter from highly-productive epilimnion. However, accumulated degradation products from these substances, other nutrients, and bottom sediment aggregation combine to limit functioning microbiocenosis. As illustrated in this text, despite the increase in prokaryote number and biomass with 
depth, their structure is simplified. Future work should elucidate the factors which have a direct impact on this phenomenon. A fundamental understanding of meromictic aquatic ecosystems requires knowledge of the diversity, distribution and function of bacterioplankton because of their importance in biogeochemical processes.

\section{REFERENCES}

Ambrosetti W, Barbanti L, 2005. Evolution towards meromixis of Lake Iseo (Northern Italy) as revealed by its stability trend. J. Limnol. 64:1-11.

Anderson RY, Dean WE, Bradbury JP, Love D, 1985. Meromictic lakes and varved lake sediments in North America. US Geol. Surv. Bull. 1607:1-19.

Boehrer B, Schultze M, 2006. On the revelance of meromixis in mine pit lakes. Proceedings $7^{\text {th }}$ Int. Conf. on Acid Rock Drainage (ICARD), St. Louis, MO, USA.

Boehrer B, Schultze M, 2008. Stratification of lakes. Rev. Geophys. 46:1-27.

Chróst RJ, Siuda W, 2006. Microbial production, utilization, and enzymatic degradation of organic matter in the upper trophogenic layer in the pelagial zone of lakes along a eutrophication gradient. Limnol. Oceanogr. 51:749-762.

Cole JJ, Pace ML, Caraco NF, Steinhart GS, 1993. Microbial biomass and cell size distribution in lakes More and larger cells in anoxic waters. Limnol. Oceanogr. 38:1627- 1632.

Crump BC, Hobbie JE, 2005. Synchrony and seasonality in bacterioplankton diversity of two temperate rivers. Limnol. Oceanogr. 50:1718-1729.

Dietz S, Lessmann D, Boehrer B, 2012. Contribution of solutes to density stratification in a meromictic lake (Waldsee/Germany). Mine Water Environ. 31:129-137.

Dunalska J, Górniak D, Teodorowicz M, Gąsecka K, 2004. Seasonal distribution of dissolved and particulate organic carbon in the water column of a meromictic lake. Pol. J. Environ. Stud 13:375-379.

Ferrari VC, Hollibaugh JTH, 1999. Distribution of microbial assemblages in the central Arctic Ocean basin studied by PCR/DGGE: analysis of a large data set. Hydrobiologia 401:55-68.

Galas J, 2003. Limnological study on a lake formed in a limestone quarry (Krakow, Poland). Pol. J. Environ. Stud. 12:297-300.

Górniak A, 1996. [Humic substances and their role in the functioning of freshwater ecosystems].[Degree Diss. in Polish]. University of Warsaw, Poland.

Górniak D, Olejnik G, Dunalska J, Teodorowicz M, Świątecki A, 2007. Bacterioplankton and the content of organic carbon in a meromictic lake. Hydrob. J. 43:69-81.

Hakala A, 2004. Meromixis as a part of lake evolution-observations and a revised classification of true meromictic lakes in Finland. Boreal Environ. Res. 9:37-53.

Hakala A, Sarmaja-Korjonen K, Miettinen A, 2004. The origin and evolution of lake study of a meromictic lake. Hydrobiologia 527:85-97.

Hongve D, 2004. Seasonal mixing and genesis of endogenic meromixis in small lakes in South Norway. Nord. Hydrol. 33:189-206.

Hudson JJ, Dillion PJ, Somers KM, 2003. Long term patterns and dissolved organc carbon in boreal lakes: the role of incident radiation, precipitation air temperature, southern oscillation and acid deposition. Hydrol. Earth Sci. 7: 390-8.

Humayoun, SB, Bano N, Hollibaugh JT, 2003. Depth distribution of microbial diversity in Mono Lake, a meromictic soda lake in California. Appl. Environ. Microbiol. 69:1030-1042.

Klimaszyk P, Joniak T, Ławniczak J, 2006. Annual changeability of thermal and oxygen conditions in a meromictic lake (Czarne Lake - Drawieński National Park). Limnol. Rev. 6:141-146.

Kondo R, Osawa K, Mochizuki L, Fujioka Y, Butani J, 2006. Abundance and diversity of sulphate-reducing bacterioplankton in Lake Suigetsu, meromictic lake in Fukui. Plankton Benthos Res. 1:165-177.

Lehours AC, Bardot C, Thénot A, Debroas D, Fonty G, 2005. Anaerobic microbial communities in Lake Pavin, a unique meromictic lake in France. Appl. Environ. Microbiol. 71:7389-7400.

Lehours A-C, Evans P, Bardot C, Joblin K, Fonty G, 2007. Phylogenetic diversity of Archaea and Bacteria in the anoxic zone of a meromictic lake (Lake Pavin, France). Appl. Environ. Microbiol., 73:2016-2019.

Muyzer G, Brinkhoff T, Nübel U, Santegoeds C, Schäfer H, Waver C, 1998. Denaturing gradient gel electrophoresis (DGGE) in microbial ecology, p. 1-27. In: A.D.L. Akkermans, J.D. van Elsas and F.J. de Bruijn (eds.), Molecular microbial ecology manual. Kluwer Academic Publ.

Muyzer G, De Waal EC, Uitterlinden AG, 1993. Profiling of complex microbial populations by denaturing gradient gel electrophoresis analysis of polymerase chain reaction-amplified genes coding for 16S rRNA. Appl. Environ. Microbiol. 59:695-700.

Norland S, 1993. The relationship between biomass and volume of bacteria, p. 303-308. In: P.F. Kemp, B.F. Sherr, E.B. Sherr and J.J. Cole (eds.), Handbook of method in aquatic microbial ecology. Lewis Publ.

Oikonomou A, Pachiadaki M, Stoeck T, 2014. Protistan grazing in a meromictic freshwater lake with anoxic bottom water. FEMS Microbiol Ecol. 87:691-703.

Øvreås L, Forney L, Daae F-L, Torsvik V, 1997. Distribution of Bacterioplankton in Meromictic Lake Sælenvannet, as Determined by Denaturing Gradient Gel Electrophoresis of PCR-Amplified Gene Fragments Coding for 16S rRNA. Appl. Environ. Microbiol. 63:3367-3373.

Parszuto K, 2008. POC, chlorophyll and pheophytin a vertical distribution in restored Kortowskie Lake (Poland). Limnological Papers 3:79-88.

Parszuto K, Tandyrak R, Galik J, 2009. Qualitative and quantitative characteristic of organic matter in the water of a small reservoir. Arch. Environ. Prot. 35:59-71.

Porter KG, Feig YS, 1980. The use of DAPI for identifying and counting aquatic microflora. Limnol. Oceanogr. 25:943-948.

Rodrigo MA, Miracle MR, Vicente E, 2001. The meromictic Lake La Cruz (Central Spain). Patterns of stratification. Aquat. Sci. 63:406-416.

Socolofsky SA, Jirka GH, 2004. Large-scale flow structures and stability in shallow flows. J. Environ. Eng. Sci. 3:451-462.

Sørensen J, 1982. Reduction of ferric iron in anaerobic, marine sediment and interaction with reduction of nitrate and sulfate. Appl. Environ. Microbiol. 43:319-324. 
Świątecki A, 1997. [The use of bacteriological indicators in assessing the quality of surface waters]. [Diss. in Polish]. Teacher Training College, Olsztyn, Poland.

Tandyrak R, Parszuto K, 2006. Multi-year investigations of organic matter in the waters of Lake Starodworskie, after phosphorus inactivation. Arch. Environ. Prot. 32:29-40.

Tandyrak R, Parszuto K, Górniak D, Kośnik P, 2009. Hydrochemical properties, bacterioplankton abundance and biomass in the meromictic Lake Starodworskie in 2004. Oceanol. Hydrobiol. St. 38:127-133.

Tandyrak R, Teodorowicz M, Grochowska J, 2010. Observations of selected chemical components of meromictic Lake Zapadłe waters in 1990-1993, 2000-2001 and 2005-2006. Arch. Environ. Prot. 36:75-82.

ter Braak CJF, Šmilauer P, 2002. CANOCO reference manual and CanoDraw for Windows user's guide: software for ca- nonical community ordination (version 4.5). Microcomputer Power, Ithaca: $500 \mathrm{pp}$.

Tonolla M, Bottinelli M, Demarta A, Peduzzi R, Dittmar H, 2005. Molecular identification of an uncultured bacterium ("morphotype R") in meromictic Lake Cadagno, Switzerland. FEMS Microbiol. Ecol. 53:235-244.

Tylmann W, Szpakowska K, Ohlendorf Ch, Woszczyk M, Zolitschka B, 2012. Conditions for deposition of annually laminated sediments in small meromictic lakes: a case study of Lake Suminko (northern Poland). J. Paleolimnol. 47:55-70.

Walker KF, Likens GE, 1975. Meromixis and a reconsidered typology of lake circulation patterns. Verh. Internat. Verein. Limnol. 19:442-458.

Yoshimura S, 1937. Abnormal thermal stratifications of inland lakes. Proc. Imp. Acad. 13:316-319. 